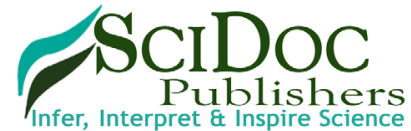

International Journal of HIV/AIDS and Research (IJHR)

ISSN 2379-1586

\title{
Varicella and Herpes Zoster in an HIV-Positive Adult
}

Elloudi $\mathrm{S}^{*}$, Baybay $\mathrm{H}^{1}$, Rabhi $\mathrm{R}^{2}$, Mernissi FZ

${ }^{1}$ Department of Dermatology and Venereology, University Hospital Hassan II Fez, Morocco.

${ }^{2}$ Department of Infectiology, University Hospital Hassan II Fez, Morocco.

\section{Abstract}

Zoster is a reactivation of the latent VZV virus that occurs years later after primary infection of varicella. The association of both is possible in immunosuppressed patients. We report a combination of varicella and herpes zoster in an HIV-positive adult.

Keywords: Varicella; Herpes Zoster; HIV Positive.

\section{Introduction}

The virus VZV (varicella zoster virus), virus of the family alpha herpesviridae is a particular in its ability to induce 2 distinct pathologies: varicella and herpes zoster. Varicella is the primary infection, whereas Zoster is the result of latent reactivation of the virus at the level of the sensory ganglia. Factors triggering the reactivation of the virus are still poorly understood, the latter being probably secondary to a deficiency of the VZV-specific cell-mediated immunity, which would explain its particular frequency in immunocompromised individuals and in particular HIV-positive persons. We report a combination of varicella and herpes zoster in an HIV-positive adult.

\section{Case Report}

A 38 years old man, without history of varicella at the childhood, without intrafamilial contamination, followed for an acquired immunodeficiency under antiviral treatment. Consulted our department for a vesicular eruption initially beginning on the face and trunk, followed after 3 days by sciatalgia with a similar eruption on the lower left limb. The dermatological examination found multiple umbilicus vesicles clear and crusty in places, resting on an inflammatory skin, with elements of different age affecting the face, the scalp, the trunk and the upper limbs evoking a varicella (Figure 1). In addition, in the left lower limb there were multiple vesicles of haemorrhagic contents with necrotic surfaces grouped together in a bouquet and following the path of the major sciatic nerve evoking a zoster infection (Figure 2). Biologically, the viral load was undetectable, and the CD4 count was $260 \mathrm{elt} / \mathrm{mm}^{3}$. The pulmonary X-ray showed no anomaly. The patient was placed under local care, an analgesic and antiviral treatment based on Aciclovir intravenously at $10 \mathrm{mg} / \mathrm{Kg} / 8 \mathrm{H}$ for 10 days, with good improvement.

\section{Discussion}

Zoster is a reactivation of the latent VZV virus, and sometimes a new exposure. The role of cell-mediated immunity in antiviral immunity is proven, as humoral immunity is not always sufficient to provide protection against VZV [1]. Thus, subjects with a deficit of cellular immunity are likely to develop more severe or atypical forms in their clinical or evolutionary presentation [2, 3]. The viral reactivation of VZV occurs years later, following factors favoring the decrease of the specificanti-cellular immunity anti-VZV. A reactivation as fast in our case is very particular little described in the literature $[1,4]$. In our patient, the diagnosis of generalized herpes zoster was excluded because there was no history of varicellla before, and because the generalized eruption preceded the zoniform eruption on the Path of the sciatic nerve. The rapid reactivation concomitant with primofection with VZV could be explained by the state of HIV immunodeficiency [4, 5]. Indeed, the occurrence of VZV infection in an HIV-positive subject would be statistically associated with a risk of progression of the disease [6]. However, the viral load in our patient remained undetectable and the CD4 level remained above $200 \mathrm{elt} / \mathrm{mm}^{3}$,

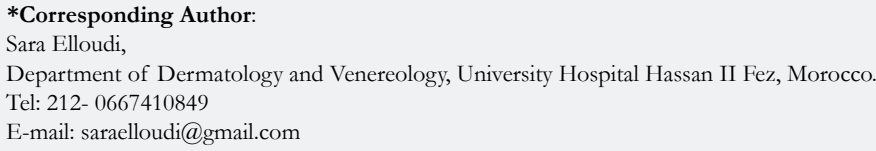

Copyright: Elloudi $\mathbf{S}^{\odot}$ 2017. This is an open-access article distributed under the terms of the Creative Commons Attribution License, which permits unrestricted use, distribution and reproduction in any medium, provided the original author and source are credited. 
Figure 1. Varicella Infection on the Trunc.

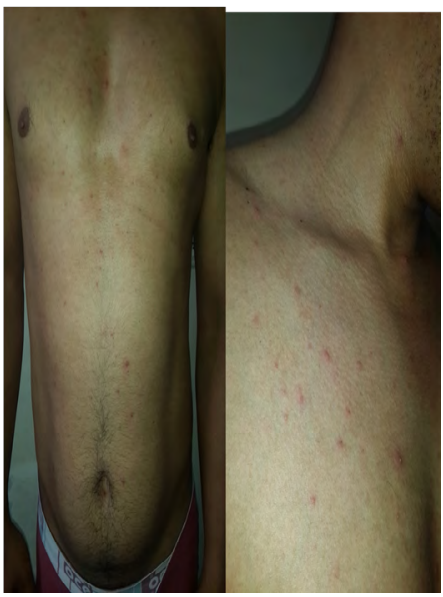

Figure 2. Herpes Zoster on the Path of the Major Sciatic Nerve.

explaining the non-aggressive clinical form in our case.

\section{Conclusion}

The association of varicella and herpes zoster in an HIV-positive adult is a possible event regardless of the immune status of the patient as evidenced by our observation. Management should be early to avoid serious and life-threatening complications.

\section{References}

[1]. PallettAP, Nicholls MW (1986) Varicella-zoster: reactivation or reinfection? Lancet. 1(8473): 160.

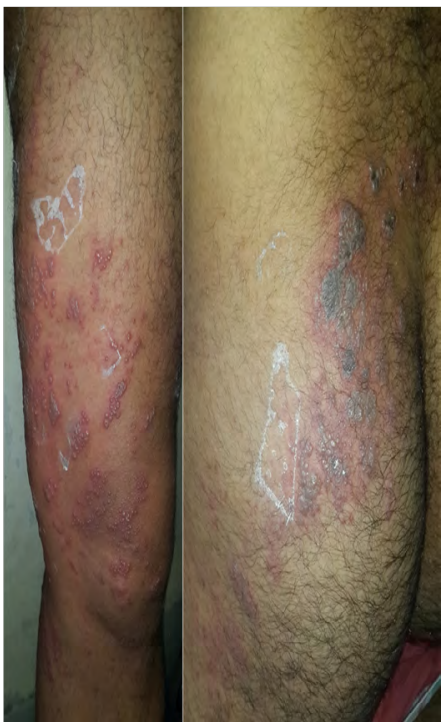

[2]. Boivin S, Catteau B, Piette F, Thomas P (2003) Cutaneous manifestations of varicellazoster virus infections in Aids immunosuppressed patients. French J Allergol Clin Immunol. 43: 261-272.

[3]. Lokke Jensen B, Weismann K, Mathiesen L, Klem Thomsen H (1999) Atypical varicella-zoster infection in Aids. Acta DermVenereol. 73(2): 123-5.

[4]. Hall S, Maupin T, Seward J, Jumaan AO, Peterson C, et al., (2002) Second varicella infections: are they more common than previously thought? Pediatrics. 109(6): 1068-73.

[5]. Perronne C, Lazanas M, Leport C, Simon F, Salmon D, et al., (1990) Varicella in patients infected with the human immunodeficiency virus. Arch Dermatol. 126(8): 1033-6.

[6]. Nilanjan Chakraborty, Sohinee Bhattacharyya, Chandrav De, Mukherjee A, Santra S, et al., (2010) Incidence of multiple Herpesvirus infection in HIV seropositive patients, a big concern for Eastern Indian scenario. Virol J. 7: 147. 